\title{
RELEVANCE OF PHARMACEUTICAL HIGHER EDUCATION TO THE LABOR MARKET: A STUDY OF PHARMACISTS' ATTITUDES
}

\author{
Todor Naydenov ${ }^{1}$, Danail Pavlov² ${ }^{2}$ Diana Ivanova ${ }^{2}$, Albena Kerekovska ${ }^{3}$, Ilko Getov ${ }^{1}$ \\ ${ }^{1}$ Bulgarian Pharmaceutical Union \\ ${ }^{2}$ Department $f$ Biochemistry, Mollar Medicine and Nutrigenomics, Faculty of Pharmacy, \\ Medical University of Varna \\ ${ }^{3}$ Department of Social Medicine and Healthcare Organisation, Faculty of Public Health, \\ Medical University of Varna
}

\section{ABSTRACT}

The role and responsibilities of pharmacists are developing and increasingly expanding. University programs need to guide pharmacists into becoming leaders of change. The objective of the following survey is to examine the attitudes among pharmacy graduates as to the level of relevance of their higher education studies to the requirements of the pharmaceutical practices and the labor market.

The overwhelming share of the participants in the survey believes higher education training is relevant to pharmaceutical practices. Nevertheless, a mere $6 \%$ state that the knowledge, skills and competences acquired in the course of higher education training relate completely to those required in the professional practice.

Keywords: pharmaceutical education, labor market

\section{INTRODUCTION}

The conventional understanding of competitive advantage as the acquisition of assets is no longer a sufficient prerequisite for business success. In a knowledge-based society, the future is defined by

\section{Address for correspondence:}

Assist. Danail Vasilev Pavlov

Department of Biochemistry, Molecular Medicine and

Nutrigenomics,

Medical University - Varna

55 Marin Drinov Str.

9002 Varna, Bulgaria

e-mail: danailpavlov@gmail.com

phone: +35952677050

Received: November 8, 2014

Accepted: December 1, 2014 the capability of the economic subject to translate knowledge into assets (1). Undoubtedly, universities are among the key knowledge sources and as such they must be supported by the European Commission by means of national universities so that the quality of higher education is improved and academic curricula are better suited to the needs of the market with a view to opening the doors of the latter to young people of a wider range of social strata (2).

Higher education is more than a production line, which releases qualified individuals. Nevertheless, to many people higher education is a springboard to a better job (3).

According to Toshev "there is a quick rise in both the number of students and the number of educational institutions. The fact that higher education is becoming a mass commodity puts its quali- 
ty at risk" (4). There is a clear tendency towards the same regarding pharmaceutical education in Bulgaria. Only within a decade the number of pharmaceutical faculties has grown from one to four. More than 350 people acquired a Master's degree in Pharmacy and the respective professional qualifications in 2013. The number of graduates is on the rise as a whole, with a trend towards intensification of the process in the near future. Overproduction of pharmacists is also observed (5). This complicates further the issue of the quality and competitiveness of higher education in relation to the requirements of the labor market.

Analyzing the challenges to Bulgarian higher education, Kozhuharov emphasizes the need for universities to base their syllabi and curricula on disciplines which will provide the necessary practical training (6).

Students in Bulgaria are mainly challenged by the inadequately developed relationship between businesses and higher education, especially at the end of the educational period, when university graduates are confronted with the difficulties of finding a job. Companies, in turn, often express dissatisfaction with graduates not being sufficiently qualified (7).

The long Bulgarian transition towards democracy and market economy has yet to give birth to coherent qualification systems to respond to the new market processes.

Particular attention should be paid to the dynamically developing sectors, such as the pharmaceutical one.

According to Sekhon and Kamboj a distinct feature of the training programmes in pharmacy is their emphasis on the career development of students. Therefore, they underline how crucial it is for the pharmaceutical education to meet the demands not only of the present but of the future as well. What is more, the last ten years have seen a substantial change in the characteristics of the pharmaceutical profession in a global perspective, including the increased demand on the labor market for specialists in this sphere of scientific knowledge (8).

The role and responsibilities of pharmacists are developing and enlarging, increasingly entailing the supply of customer-oriented services. This tendency is highly likely to continue in the future.
Consequently, programs in pharmacy have to be transformed and redesigned so as to be compliant with these new requirements. They have to be redesigned so that pharmacy graduates can meet society's health-related needs and expectations, as well as to manage the wide range of tasks in the pharmaceutical practices (9).

According to Marriott and Co. university programs need to guide pharmacists into becoming pioneers of change so that they can uphold high standards of professional competence, providing services that can be very different from what pharmacies offer now. Curricula have to be instrumental in equipping specialists with the optimal minimum of skills in all spheres - basic sciences, clinical sciences, pharmacological practices. Every new graduate has to be capable of building upon the basic knowledge acquired at university throughout their professional life (10).

The objective of the following survey is to examine the attitudes among pharmacists as to the level of relevance of their higher education studies to the requirements of the pharmaceutical practice and the labor market.

The survey is part of the project 'Redefinition and approbation of the academic curricula and syllabi of the Faculty of Pharmacy at the Medical University 'Prof. Dr. Paraskev Stoyanov' - Varna in compliance with the needs and requirements of the labor market' run within the framework of the European Social Fund - European Commission Operational Programme "Human Resources Development".

The research team expresses gratitude to all participants in the survey and the project experts.

\section{METHODS AND RESOURCES}

With a view to attain the aims and objectives of this research a three-section questionnaire was designed. The first section contains demographic information on the age, sex and professional experience of the respondents. The second contains eleven questions on pharmacists' opinion as to the relevance of their higher education to the requirements of the pharmaceutical practice and the labor market. The third block of questions contains evaluations on the conditions and quality of training higher education provides as well as on the importance various competences hold for the career development of pharmacists. The respondents were asked to rate the above 
Todor Naydenov, Danail Pavlov, Diana Ivanova et al.

mentioned on the Likert scale, ranging from "a definite no" to "a definite yes" and from "very important" to "not important". The questionnaire contains one open question for additional comments.

The questionnaire is compliant with the system of criteria for analysis and assessment of the educational needs of the pharmaceutical business environment, which is part of the project "Redefinition and approbation of the academic curricula and syllabi of the Faculty of Pharmacy at the Medical University 'Prof. Dr. Paraskev Stoyanov' - Varna in compliance with the needs and requirements of the labor market."

The research was carried out on the territory of the six planning regions in Bulgaria - southwest, south-central, south-east, north-east, north central and north-west. The questionnaire was completed by the respondents and submitted back to the researchers in strict compliance with anonymity requirements. The research was conducted in the period November 2013 - February 2014. The results were analyzed by means of statistical software. Thematic analysis was carried out.

\section{RESULTS AND ANALYSIS}

\section{Demographic features:}

100 pharmacists were interviewed, $71 \%$ of whom were females, which is a predictable share in view of the fact that the profession has feminized as the Register of the Masters of Pharmacy of the Bulgarian Pharmaceutical Union indicates.

The highest percentage of the respondents (41\%) belongs to the $30-45$ age range. $29 \%$ are between 18

\section{Professional experience}

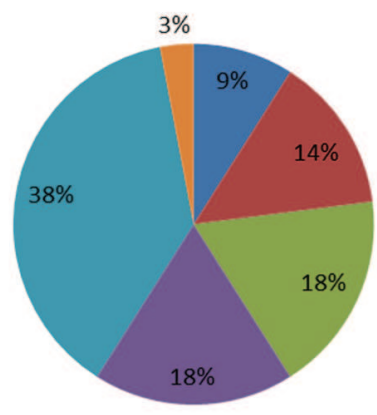

- Over 30 years

- 21-30 years

=11-20 years

- 6-10 years

mup to 5 years

Without recourse

Fig. 1. Professional experience of masters in pharmacy (a separate group in the National Professions and Occupations Register) and 30 years of age, $21 \%$ are in the $45-60$ age range, with those over 60 accounting for $9 \%$. This age profile differs from that of the Register of the Masters of Pharmacy of the Bulgarian Pharmaceutical Union. At the same time, the higher percentage of respondents up to the age of 30 is noteworthy as most of them have graduated in a period of less than 5 years.

The above mentioned age profile is closely related to the professional experience profile of the respondents. More than half of the interviewees have professional experience of fewer than 10 years.

The overwhelming share of the respondents (81\%) work in pharmacies, $47 \%$ of them being pharmacy managers. $4 \%$ are specialists on quality control and clinical study monitoring. Production technologists comprise $4 \%$, specialists on medicinal products safety and registration account for 3\%. The unemployed masters in pharmacy who took part in the survey represent $3 \%$ of all respondents.

$9 \%$ of the interviewees are owners of the company they work in, while hired workforce comprise 91\%.

The highest percentage of the respondents (62\%) has worked for their present-day employer for fewer than 5 years, with $15 \%$ of them for up to one year. Those who have spent between 5 and 10 years at their workplace represent $18 \%$, while $20 \%$ have spent more than 10 years.

$58 \%$ of the interviewees work in companies with a workforce with up to ten employees; $21 \%$ - between 11 and 25 employees; $8 \%$ - between 26 and 50, and $4 \%$ - between 51 and 100. Those who work in a company with more than 100 employees account for $3 \%$.

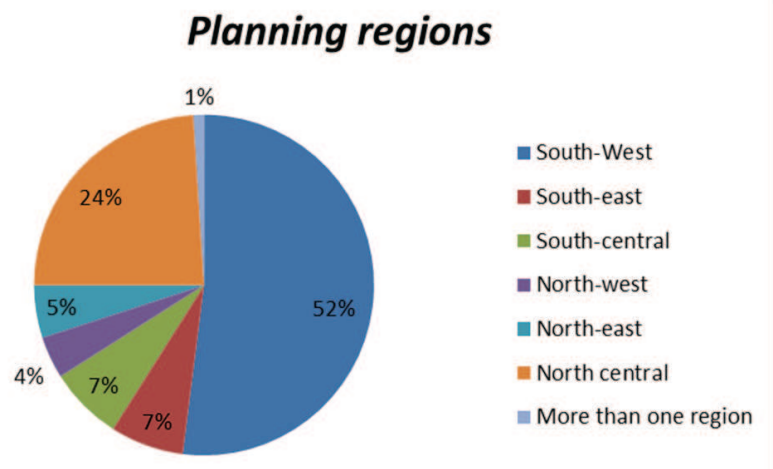

Fig. 2. Breakdown of the respondents by planning regions 
The sample is representative as the respondents are from the six planning regions in Bulgaria - south-west, south-central, south-east, north-east, north central and north-west. The breakdown by regions can be seen on figure 2 .

Level of relevance of higher education to the requirements of the pharmaceutical practice and the labor market.

The majority of respondents (71\%) believe that higher education is relevant to the practice. Then again, it is an alarming fact that only $6 \%$ say the knowledge, skills and competences acquired at university correspond to those required in practice, while $65 \%$ believe they do not. Only $2 \%$ do not find any relevance, with $27 \%$ holding the opinion they are irrelevant rather than not.

The most common challenge pharmacists are confronted with is the inadequacy of the practical skills and key competence training the university provides - an opinion of $64 \%$ of the study respondents. $41 \%$ believe that the problem is in the discrepancy between the academic curriculum and professional practice. The causes behind this are rooted in the dynamics with which both the economy and the pharmaceutical market develop. The revisions of a range of regulatory acts on both national and $\mathrm{Eu}-$ ropean level have made it necessary for an increasing number of pharmacists over the last two decades to develop professionally in untypical spheres. Along with that, new perspectives for career development have opened up - non-existent before the beginning of the period of socio-political changes. In addition, a factor is also the foreign economic structures with responsibilities in a regional as well as global perspective.

Any professional development in these spheres undeniably requires new competences such as teamwork and communication skills, often in an international environment, expertise related to information and communication tools, a high command of foreign languages, etc. $33 \%$ of the respondents feel they have not acquired those in the course of their higher education.

It is also noteworthy that $36 \%$ of those who gave the above mentioned answer belong to the group of the respondents whose working experience is up to ten years, or approximately $21 \%$ of that group sup- port this view. An explanation for the latter could be found in the fact that the pharmacists from that group show particular interest in the above mentioned spheres.

Another area of disparity is related to the "equipment and technologies" used in the pharmaceutical practice. $26 \%$ of the interviewees are of the opinion that university education has not adequately provided them with the necessary skills. Providing such skills, however, might be difficult due to the quick-paced technological development. The university should provide basic training, while any further knowledge and competences development should be a joint responsibility of the university, organizers of any continuing medical education courses and pharmacists themselves.

Overall, the research makes it clear that pharmacists would like to see a change in academic curricula and syllabi so that those are better providers of practical competences.

$71 \%$ of the respondents consider practical competences - i.e. what pharmacists need to know and be able to do, as well as the expertise as to how to do it - is what is of the greatest importance in higher education. In contrast, $14 \%$ define theoretical knowledge as the most important, while those who say the same of practical skills account for $15 \%$.

$73 \%$ of the interviewees define the quality of practical training' as the aspect universities have to improve, so that students are better equipped for professional practice. To compare, $29 \%$ consider that it is 'the quality of theoretical training' that should be raised in higher education. The respondents have provided more than one answer. The remaining responses emphasize 'the relevance and comprehensiveness of academic curricula' (56\%); 'the efficiency of the teaching and assessment methods' (50\%), 'the participation of students in projects and scientific research' (45\%); 'the equipment' (33\%); 'the levels of competence and commitment of tutors and professors (32\%).

An analysis of the responses to the question 'Which is the most important professional quality that holders of a masters degree in pharmacy lack?' shows an emphasis on practical knowledge and skills, including '....a sense of community' and '... teamwork skills'. 


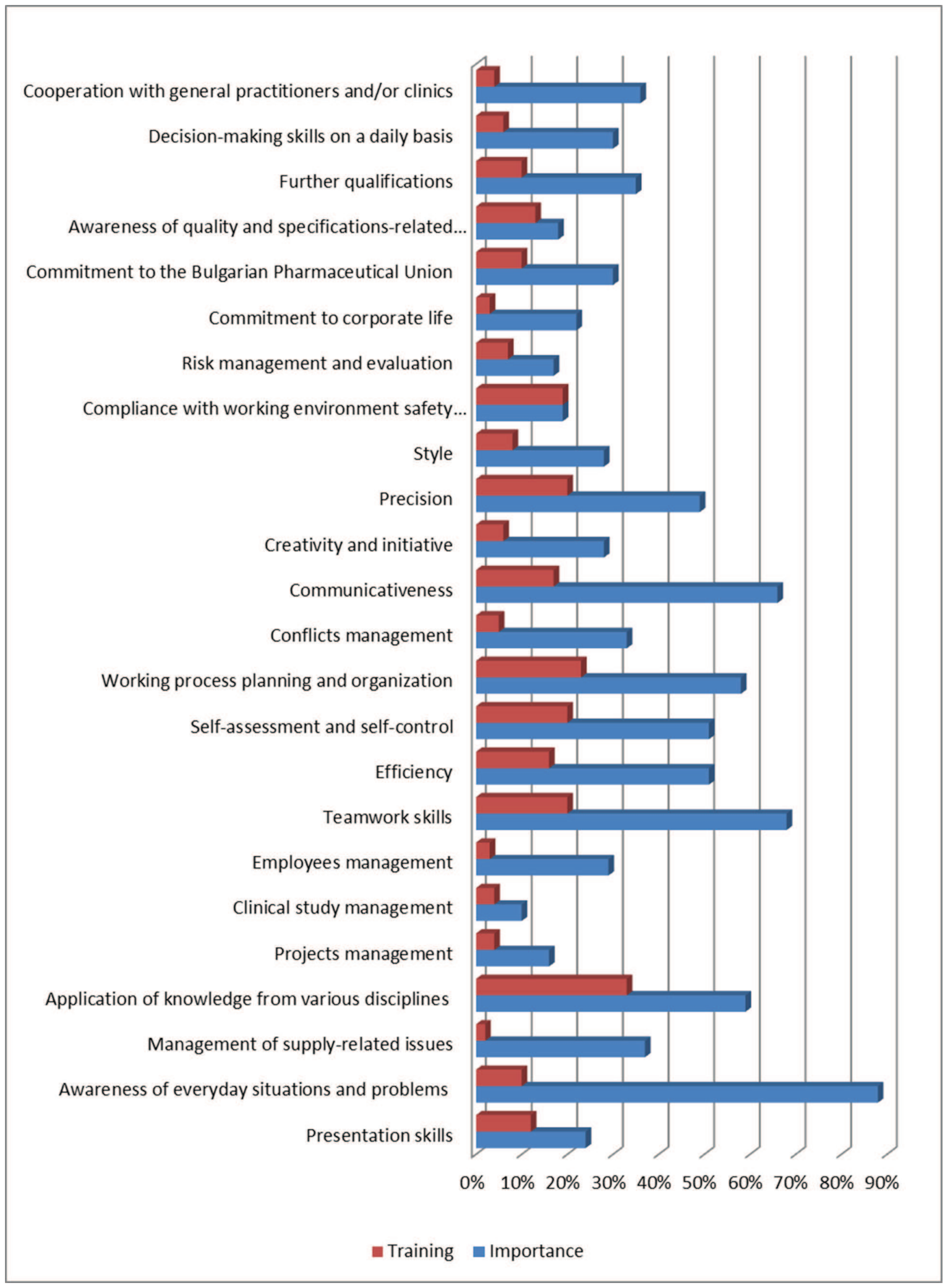

Fig. 3. Importance and quality of key competences training 
Relevance of pharmaceutical higher education to the labor market: a study of pharmacists' attitudes

Some respondents stress the lack of communication skills in terms of relationships both in and outside the working environment. It is also worth paying attention to the lack of foreign language education respondents point to. On the one hand, this hinders both the performance of career-related duties and overall career development, especially when it comes to overseas subsidiaries and companies committed to clinical studies. On the other hand, it also creates difficulties in terms of accessing various sources of information on the latest developments in medicine, including international databases and internet-based medical journals. Generally, language training is not in focus in pharmacy academic cur- ricula. It is therefore crucial that a change is initiated with a view to providing students with the opportunity to enroll in optional language courses.

Other respondents highlight the lack of 'entrepreneurship skills', ‘...managerial skills', ‘...businessrelated knowledge' and '...independent decision-taking.' Emphasis is put as well on 'the lack of knowledge as to trade marks'; '....awareness of drugs clinically approved over the last 5 to 7 years', 'knowledge about drugs combinations and side effects', as well as '...experience in key disciplines: pharmaceutical care and pharmacology'.

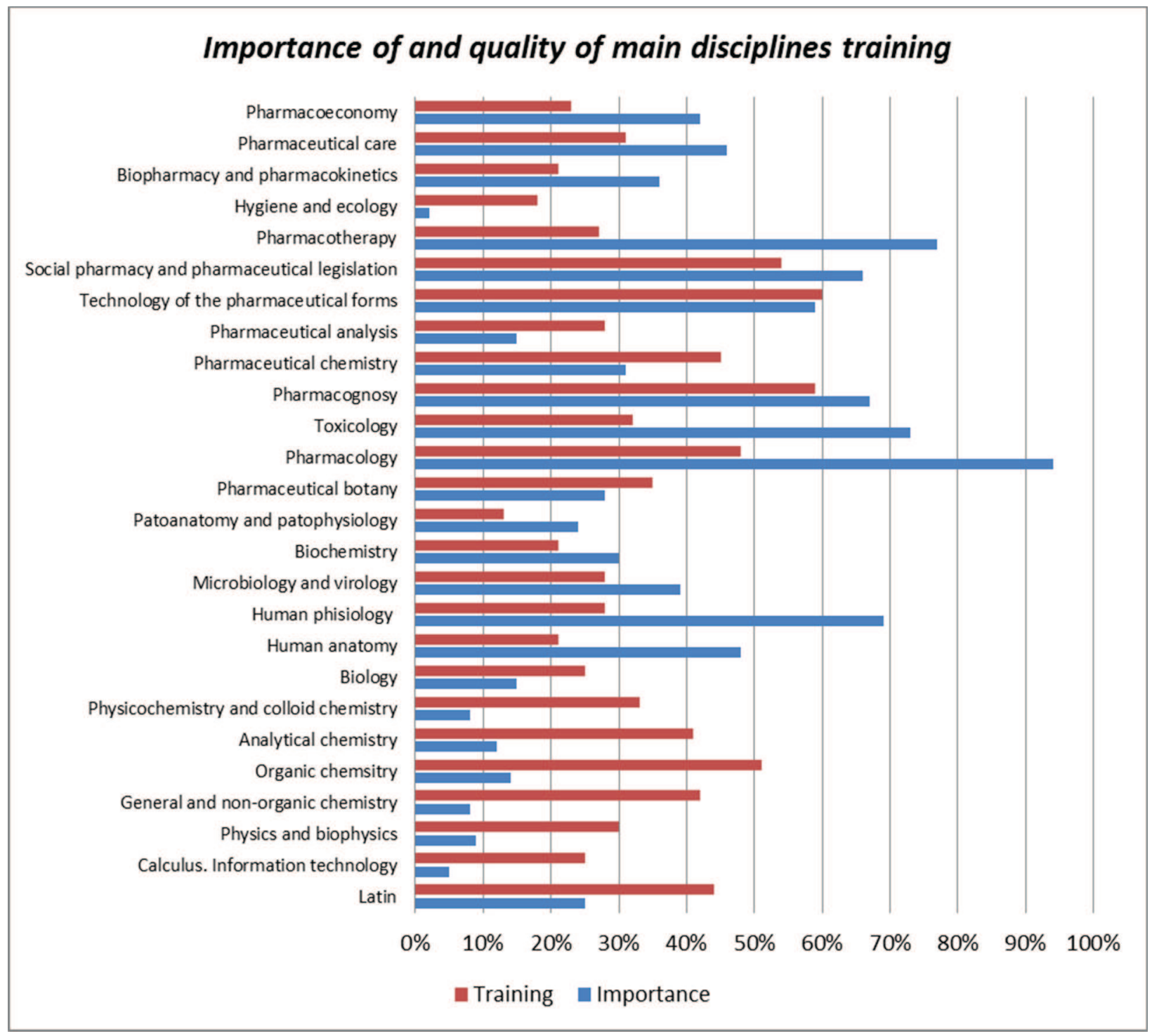

Fig. 4. Importance and quality of main disciplines training 
Table 1. Training and other higher education parameters evaluation

\begin{tabular}{|c|c|c|c|c|c|c|}
\hline № & Criteria & $\begin{array}{l}\text { Fully } \\
\text { agree }\end{array}$ & $\begin{array}{l}\text { Would } \\
\text { rather } \\
\text { agree }\end{array}$ & $\begin{array}{l}\text { Would } \\
\text { rather } \\
\text { disagree }\end{array}$ & $\begin{array}{c}\text { Fully } \\
\text { disagree }\end{array}$ & $\begin{array}{l}\text { Cannot } \\
\text { decide }\end{array}$ \\
\hline 1 & I am content with the theoretical training & $29 \%$ & $54 \%$ & $15 \%$ & $1 \%$ & $1 \%$ \\
\hline 2 & $\begin{array}{l}\text { The curriculum provides a wide range of } \\
\text { lecture courses }\end{array}$ & $28 \%$ & $52 \%$ & $14 \%$ & $2 \%$ & $4 \%$ \\
\hline 3 & $\begin{array}{l}\text { The curriculum is designed with a view to } \\
\text { comprehensive knowledge provision }\end{array}$ & $25 \%$ & $51 \%$ & $17 \%$ & $0 \%$ & $7 \%$ \\
\hline 4 & $\begin{array}{l}\text { I was well-informed about my career-related } \\
\text { opportunities }\end{array}$ & $9 \%$ & $28 \%$ & $40 \%$ & $19 \%$ & $4 \%$ \\
\hline 5 & The number of practical seminars is sufficient & $16 \%$ & $40 \%$ & $32 \%$ & $8 \%$ & $4 \%$ \\
\hline 6 & $\begin{array}{l}\text { Practical seminars provide the opportunity to } \\
\text { apply the theoretical knowledge acquired in } \\
\text { lectures. }\end{array}$ & $8 \%$ & $46 \%$ & $34 \%$ & $10 \%$ & $2 \%$ \\
\hline 7 & $\begin{array}{l}\text { Tutors provide guidance through assigning } \\
\text { projects (term papers, research assignments) }\end{array}$ & $3 \%$ & $19 \%$ & $40 \%$ & $31 \%$ & $7 \%$ \\
\hline 8 & $\begin{array}{l}\text { Foreign language classes facilitated my access to } \\
\text { foreign language materials }\end{array}$ & $17 \%$ & $20 \%$ & $24 \%$ & $31 \%$ & $8 \%$ \\
\hline 9 & $\begin{array}{l}\text { The academic curriculum includes practical } \\
\text { training outside the compulsory internship }\end{array}$ & $3 \%$ & $11 \%$ & $25 \%$ & $49 \%$ & $12 \%$ \\
\hline 10 & $\begin{array}{l}\text { The internship is in line with the academic } \\
\text { curriculum }\end{array}$ & $6 \%$ & $22 \%$ & $43 \%$ & $21 \%$ & $8 \%$ \\
\hline 11 & $\begin{array}{l}\text { Tutors are knowledgeable and apply efficient } \\
\text { teaching methods }\end{array}$ & $18 \%$ & $61 \%$ & $15 \%$ & $4 \%$ & $2 \%$ \\
\hline 12 & $\begin{array}{l}\text { Tutors provided a wide range of materials to } \\
\text { assist me in the learning process }\end{array}$ & $9 \%$ & $47 \%$ & $27 \%$ & $14 \%$ & $3 \%$ \\
\hline 13 & $\begin{array}{l}\text { Tutors delivered lectures and seminars regularly } \\
\text { in accordance with the curriculum }\end{array}$ & $35 \%$ & $50 \%$ & $10 \%$ & $2 \%$ & $3 \%$ \\
\hline 14 & I could approach the tutors in person & $25 \%$ & $49 \%$ & $10 \%$ & $9 \%$ & $7 \%$ \\
\hline 15 & $\begin{array}{l}\text { Tutors were always responsive to my queries and } \\
\text { provided adequate feedback }\end{array}$ & $21 \%$ & $52 \%$ & $12 \%$ & $5 \%$ & $10 \%$ \\
\hline 16 & $\begin{array}{l}\text { Contacts with tutors are a motivating factor in } \\
\text { research work and continuing education }\end{array}$ & $8 \%$ & $22 \%$ & $34 \%$ & $23 \%$ & $13 \%$ \\
\hline 17 & $\begin{array}{l}\text { The assessment criteria are just and further the } \\
\text { personal development of graduates }\end{array}$ & $7 \%$ & $33 \%$ & $31 \%$ & $18 \%$ & $11 \%$ \\
\hline 18 & $\begin{array}{l}\text { Most of the tutors make use of technology in the } \\
\text { teaching process }\end{array}$ & $3 \%$ & $42 \%$ & $41 \%$ & $8 \%$ & $6 \%$ \\
\hline 19 & $\begin{array}{l}\text { The university provides opportunities for } \\
\text { overseas education }\end{array}$ & $7 \%$ & $27 \%$ & $25 \%$ & $25 \%$ & $16 \%$ \\
\hline 20 & $\begin{array}{l}\text { Exam results and credits from overseas courses } \\
\text { are recognised in my university }\end{array}$ & $3 \%$ & $10 \%$ & $21 \%$ & $10 \%$ & $56 \%$ \\
\hline 21 & $\begin{array}{l}\text { The university provides the opportunity for } \\
\text { participation in research and development } \\
\text { projects outside the academic curriculum }\end{array}$ & $9 \%$ & $24 \%$ & $30 \%$ & $20 \%$ & $17 \%$ \\
\hline
\end{tabular}


Relevance of pharmaceutical higher education to the labor market: a study of pharmacists' attitudes

\begin{tabular}{|c|c|c|c|c|c|c|}
\hline 22 & $\begin{array}{l}\text { Practical seminars provided the opportunity to } \\
\text { participate in research and development projects }\end{array}$ & $10 \%$ & $12 \%$ & $29 \%$ & $36 \%$ & $13 \%$ \\
\hline 23 & $\begin{array}{l}\text { Learning halls (including computer rooms and } \\
\text { laboratories) are in good condition }\end{array}$ & $17 \%$ & $52 \%$ & $16 \%$ & $11 \%$ & $4 \%$ \\
\hline 24 & $\begin{array}{l}\text { Technical equipment is up-to-date and in good } \\
\text { condition }\end{array}$ & $13 \%$ & $46 \%$ & $25 \%$ & $12 \%$ & $4 \%$ \\
\hline 25 & $\begin{array}{l}\text { The university provided me with the opportunity } \\
\text { to make use of the technical equipment } \\
\text { necessary for my research }\end{array}$ & $6 \%$ & $35 \%$ & $20 \%$ & $12 \%$ & $27 \%$ \\
\hline 26 & $\begin{array}{l}\text { Seminars and lectures are well-spaced time-wise } \\
\text { so that students time is not wasted }\end{array}$ & $13 \%$ & $46 \%$ & $17 \%$ & $13 \%$ & $11 \%$ \\
\hline 27 & Libraries provide a wide range of materials & $12 \%$ & $31 \%$ & $26 \%$ & $19 \%$ & $12 \%$ \\
\hline 28 & $\begin{array}{l}\text { The university provides good sport and social } \\
\text { life opportunities }\end{array}$ & $7 \%$ & $23 \%$ & $30 \%$ & $29 \%$ & $11 \%$ \\
\hline 29 & $\begin{array}{l}\text { The university career centre provides adequate } \\
\text { consultation, training, internships and job } \\
\text { opportunities guidance }\end{array}$ & $4 \%$ & $9 \%$ & $29 \%$ & $37 \%$ & $21 \%$ \\
\hline 30 & $\begin{array}{l}\text { The club of students who have graduated } \\
\text { organised meetings and provided essential } \\
\text { information as to career -related opportunities }\end{array}$ & $4 \%$ & $8 \%$ & $29 \%$ & $39 \%$ & $20 \%$ \\
\hline 31 & $\begin{array}{l}\text { The university provided the opportunity for } \\
\text { regular contact with employers }\end{array}$ & $2 \%$ & $5 \%$ & $28 \%$ & $52 \%$ & $13 \%$ \\
\hline 32 & $\begin{array}{l}\text { I had the confidence I will succeed in life and } \\
\text { established useful contacts in the course of my } \\
\text { university education }\end{array}$ & $8 \%$ & $25 \%$ & $30 \%$ & $26 \%$ & $11 \%$ \\
\hline
\end{tabular}

Fig. 4 compares the importance of knowledge and skills taught in the compulsory academic disciplines as laid down in the Uniform State Requirements for Master's degree in Pharmacy on the one hand, and respondents' opinion of the quality of training provided in the course of university education on the other.

The respondents' answers reflect as well the above mentioned new developments in the pharmaceutical profession. 97\% of them define 'Pharmacology' as a discipline of central importance, while $73 \%$ say the same of 'Pharmacotherapy'. 'Toxicology' is seen as a competence of key importance by $73 \%$ of the interviewees. Disciplines related to Chemistry, namely Organic chemistry, Analytical chemistry and Physical chemistry and Colloid chemistry were mentioned by a far lower percentage of people.

It is also noteworthy that certain disciplines are seen as important for one's career development by less than $10 \%$ of the respondents. 'Hygiene and Ecol-

ogy' and 'Calculus' are a case in point - those were mentioned by $2 \%$ and $5 \%$ respectively.

The discrepancy between the importance of those disciplines and the emphasis university training places on them is also worth noting.

Interestingly, pharmaceutical technology have approximately equal performance. The fact is that the preparation of medicines in pharmacies is losing its importance during the past decades. At the same time elucidation of drug transport mechanisms through the tissues, current pharmaceutical technologies have been focused on alternative drug delivery pathways and incorporation of drug molecules into novel drug delivery systems. Moreover, in recent years many leading companies producing cosmetic products use novel technology such as nanotechnology in their work to achieve better penetration, sustained effect, increase of the UV-protection of the skin, protection from the harmful effects of environmental factors. 
Cooperation between universities and other stakeholders

It is crucial that partnerships are established and all stakeholders participate actively in the academic learning process and that those partnerships are maintained in both formal and non-formal continuing education so that higher education can meet the requirements of the socio-political life and the labor market.

When it comes to need for academic curricula to be adapted to the practice, the majority of respondents (56\%) believe in the need of 'universitiesindependent analysis of the requirements related to pharmaceutical practice' to be carried out. Furthermore, $44 \%$ of them believe it is necessary for 'thematic discussions between business representatives and tutors' to be held. All of the above mentioned clearly indicate lack of cooperation between universities and other stakeholders.

Results also show the need for prominent pharmacy specialists to participate in the teaching process in terms of practical training. $73 \%$ of the pharmacists suggest this should happen under the form of 'practical training'. As the respondents gave more than one answer, $50 \%$ of them believe 'seminars and practical sessions' should be organized, with $44 \%$ mentioning 'short-term summer internships'. A far smaller share of respondents gave 'specialized theoretical courses' (25\%) and 'key lectures' as answers (30\%).

Another finding of interest is that $58 \%$ of the respondents believe leading pharmaceutical specialists should participate actively in the continuing medical education of students.

The system for continuing education is defined by the Law on Health. The Bulgarian Pharmaceutical Union should have the responsibility to organize, coordinate, conduct and register the continuing education of the graduate students.

The control over this activity should be in accordance with the rules laid down by the Minister for Health $(11,12)$.

The Bulgarian Pharmaceutical Union implements the Law on Health and the Union Charter in coordination with the higher education institutions, the Bulgarian Red Cross and the Military Medical Academy.
In a previous survey into the attitudes of pharmacists as to the system of continuing education in Bulgaria and the scope for its enhancement, the over-

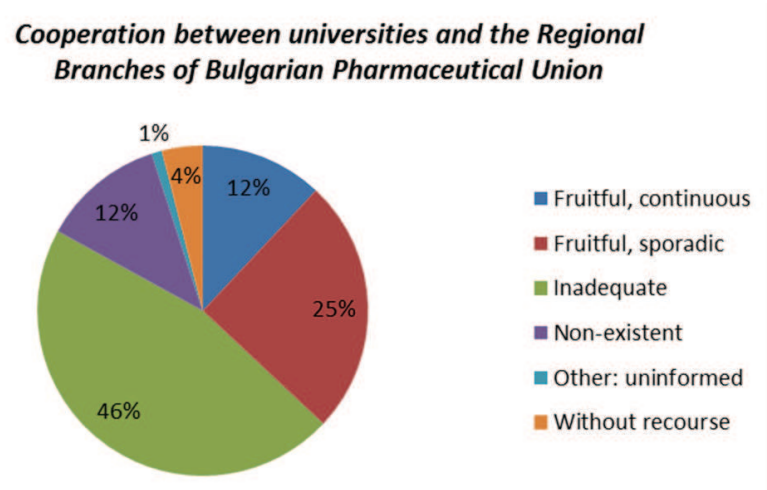

Fig. 5. Cooperation between universities and the Register of the Regional Branches of Bulgarian Pharmaceutical Union

whelming share of the respondents (on leading positions in the central and regional management bodies of the Bulgarian Pharmaceutical Union) express satisfaction with the cooperation between universities and the Bulgarian Pharmaceutical Union. In evidence of this, respondents mention the support the Union extends to the academic community, the range of continuing education activities within the Regional Branch of the Union (of under 100 members) as well as a finalized joint project of the Pharmaceutical Faculty of the Medical University in Sofia and the Bulgarian Pharmaceutical Union (13).

Most of the established partnerships are between the central government entities (the Management Board and the Quality Control Committee) including the cases when events were held on the premises of the Register of the Regional Branches. This is probably the reason why there is a discrepancy between the above mentioned evaluation and the one respondents in the current survey give to the cooperation between universities and the pharmaceutical associations, with $46 \%$ defining it as inadequate.

Regarding the relevance of higher education to the pharmaceutical practices, respondents' evaluations are even more negative. $58 \%$ define it as inadequate, while $17 \%$ report complete irrelevance. Those who see it as fruitful but sporadic account for $18 \%$, with a mere $6 \%$ describing it as fruitful and continuous. 
Relevance of pharmaceutical higher education to the labor market: a study of pharmacists' attitudes

These results are not surprising. The report 'Innovation BG 2103', section 'Innovation promoting sector competitiveness - Pharmacy' indicates that the academic community, the industry and the institutions still lack full awareness of the necessity of active partnership, applying thus a model, according to which pharmaceutical innovations are reduced to the production units and the research laboratories (15).

The latter relates to the partnership academic community - pharmacists to an even greater extent. At present none of the medical universities has developed a university enterprise project, which is common practice with a number of universities across the country. This significantly hampers cooperation opportunities.

\section{CONCLUSION}

The overwhelming share of the participants in the survey believes higher education training is relevant to the pharmaceutical practices. Nevertheless, a mere $6 \%$ state that the knowledge, skills and competences acquired in the course of higher education training complete relate to the those required in the professional practice.

Most often graduates feel challenged by the fact that, in the course of university training, practical skills and competences remain inadequately developed.

Dynamic developments in the socio-cultural life are reshaping the pharmaceutical profession. Pharmacists meet new career development opportunities but new challenges as well. Therefore, new competences need to be developed - teamwork and communication skills, often in an international environment, expertise related to information and communication tools, etc. Three out of ten interviewees hold the opinion they have not acquired those in the course of their higher education.

Survey results show high satisfaction rates when it comes to theoretical instruction and lower ones as far as practical training is concerned. Overall, the survey indicates graduates would like to see academic curriculum and syllabuses redesigned, so that the latter can further the acquisition of practical skills to a greater extent.

Partnerships and the inclusion of all stakeholders in the course of higher education training are also of crucial importance. However, survey results illustrate a lack of cooperation between universities and other stakeholders, including practising professionals, employers and professional associations.

Pharmacy graduates attach great importance to continuing medical education. More than half of the respondents would like to see the involvement of leading pharmacy professionals in their postgraduate education.

\section{REFERENCES}

1. Касърова В., Университетите като институция за учене през целия живот, Човешки Ресурси, 2012;5(215):26-28.

2. Available from: http://ec.europa.eu/news/ culture/110926_bg.htm

3. Lowden K., Hall S., Elliot D., Lewin J., Employers' perceptions of the employability skills of new graduates, Edge Foundation 2011, ISBN 978-0-95656043-8, www.edge.co.uk

4. Тошев Б., Световна класация на престижните университети: поуки за българското висше образование, Сп. „Наука”, С., СУБ, 2004 кн. 2.

5. Naydenov T., Review of inequities in provision of medicines and pharmaceutical care in Bulgaria, Соціальна фармація: стан, проблеми та перспективи: міжн. наук.-практ. інтернетконференції, 17-20 березя 2014 р. 16-26, ISSN 2311-8849.

6. Кожухаров Х., Проблеми пред българското висше образование, http://research.unwe.bg/br9/ nt-h.kojuharov.pdf

7. Available from: http://www.1989plus.com/wp-content/uploads/2011/08/Think-tank_1_education.pdf

8. Sekhon B., Kamboj S., Pharmaceutical education and careerñan overview. J Pharm Educ Res, 2011;2(1):73-86.

9. Arakawa N., Carrasqueira J., John C., FIPEd Global Education Report, Part 2, 2013, 7-10.

10. Marriott J., Nation R., Roller L., Costelloe M. Galbraith K., Stewart P., Charman W., International pharmacy education supplement, Pharmacy Education in the Context of Australian Practice. 1-12.

11. Закон за здравето, в сила от 01.01.2005 г., Обн. ДВ. бр.70 от 10 Август 2004г., последно изменен и допълнен ДВ. бр.1 от 3 Януари 2014 г.

12. Закон за съсловната организация на магистърфармацевтите, Обнародван. ДВ. бр.75 от 12 
Септември 2006 г., последно изменен. ДВ.

бр.101 от 28 Декември 2010г.

13. Найденов Т, Дечева Ц., Гетов И., Проучване на нагласите на фармацевтите, свързани със системата на продължаващото обучение на магистър фармацевтите в България и възможностите за нейното развитие (под печат).

14. Галев Т., и колектив, Иновации.бг Иновационният потенциал на България: възможности и предизвикателства, Иновациите в подкрепа на секторната конкурентоспособност, Фармация, 80-102 стр. Фондация "Приложни изследвания и комуникации” 2013, ISSN 1313-1052. 